\title{
SOUTH ASIA AND SOUTH ASIANS IN THE WORLDWIDE WEB OF ANTI-COLONIAL SOLIDARITY
}

\author{
Carolien Stolte
}

\section{Introduction}

Over the past two decades the historiography of South Asia has broken out of the local, communal, and national moulds in which it was long cast. This has been accompanied by increasing attention on the ways in which South Asian anti-imperialists organised across borders. Between the opening years of the twentieth century and the outbreak of the European phase of the Second World War, anti-imperialist internationalism thrived on a hitherto unprecedented scale. As the worldwide web of communication and transport possibilities expanded rapidly, so too did the circulation of people and ideas. Both provided an enormous impetus for international associational life, and a desire for international mobilisation around specific political, social, and religious causes. These developments had a major impact on the emerging anti-imperialist movement in colonial South Asia. In turn, South Asian anti-imperialists played an important role in shaping a worldwide web of anti-colonial solidarity in this era.

\section{Routes of anti-colonial solidarity}

What is anti-colonial solidarity, and who participated in this 'worldwide web'? During the period between 1905 and 1939 anti-colonial solidarity refers to individuals and associations organising themselves according to the belief that all territories under colonial domination were united by a shared set of problems that were best fought collectively, and that a more equitable and just world order could be achieved only by ending Euro-American imperialism. In South Asia, anti-colonial internationalists were found across the full breadth of the ideological and religious spectrum. They also hailed from all walks of society. They were illiterate lascars and renowned scholars, expatriate revolutionaries and settled social workers, members of secret societies as well as mass organisations. As a consequence, anti-colonial internationalism meant different things to different people. All anti-colonial internationalists shared a sense of kinship with others suffering under colonial domination, and an anti-imperialist 
agenda. They did not necessarily share a vision for a postcolonial world order, or the means by which to achieve it.

South Asia's location at the crossroads of multiple sea and land routes played a large role in shaping the engagements of anti-colonial internationalists. The attraction to South Asian activists of metropolitan hubs such as London, New York, and San Francisco has been well documented. ${ }^{1}$ Telegraph and shipping lines connected these hubs to the entire world, and their educational institutions attracted a global, if elite, student body. For elite South Asian students, the fact that these cities were also relatively anglophone was an additional draw, but this was certainly not a necessary condition. As the number of South Asian students abroad started to grow, so did the number of students and student activists in places such as Paris, Zurich, and Rome. ${ }^{2}$ It is important to note, however, that there were major centres far away from Western Europe and the United States that offered a similar blend of cosmopolitan population, rich associational life, relative anonymity, and distance from watchful British eyes. It is with an eye on these other centres that the diversity of anti-colonial nationalism is brought into view.

After Japan's victory over Russia in the war of 1904-5, Japan became an increasingly attractive destination. ${ }^{3}$ Although the partition of Bengal and subsequent unrest in India pushed some radical anti-imperialists to continue their political work abroad, Japan pulled a considerable number of them in by offering space in its academe, such as establishing a professorship in 'Hindustani' at Tokyo University in 1909, offering cheap student accommodation, and providing a public sphere open to the circulation of pan-Islamic and pan-Asian ideas both in Japanese and in other languages. The Anglo-Japanese Alliance demanded a precarious balance between support of South Asian anti-colonial activists and sharing information on their movements and actions with British intelligence services. Nevertheless, the existence of organisations such as the Zen Ajia Kyokai (Pan-Asiatic Society, 1924) and its inclusion of Indian activists at its gatherings, as well as in its journal Ajia, helped to connect South Asian anti-colonial activists to their counterparts from across East and South-East Asia and publicise their struggle. ${ }^{4}$

If Japan offered an alternative to existing metropolitan connections after 1905, the First World War opened new anti-colonial routes as well. Several anti-colonial revolutionaries who were resident in Europe became regular visitors to Berlin, including Shyamji Krishnavarma and Har Dayal. The German Empire explicitly and openly funded anti-British activities as part of its Weltpolitik. ${ }^{5}$ The most striking example of these was the Niedermayer-Von Hentig Expedition, a combined German, Turkish, and Indian initiative to persuade independent heads of state in Asia, particularly King Habibullah of Afghanistan, to declare war against the British. German orientalists and Indian revolutionaries prepared for their Afghan mission by recruiting Pashtunspeaking Afridi soldiers from German prison camps. ${ }^{6}$ The group left for Istanbul in April 1915, another spoke in the anti-colonial web, especially in the late nineteenth century and the early twentieth. ${ }^{7}$ They continued from there, armed with Ottoman emissaries as well as letters from the Sultan, signed as Khalifa of the community of the faithful. For most participants, the expedition was not a success. Habibullah carefully guarded Afghanistan's neutrality in the face of increasing opposition from more bellicose elements of Afghan society, and the German and Turkish diplomats waited in vain for Afghan commitments. The Indian revolutionaries succeeded not only in recruiting Indians in Afghanistan to their cause, however, but also in securing the release of Indian political prisoners in Kabul, and even declared a 'government of free India in exile', which operated several successful foreign missions before losing Afghan support. ${ }^{8}$

In the wake of the Bolshevik revolution, Tashkent similarly emerged as an inviting location for anti-colonial activists. This was the first step in a pragmatic relationship that would grow stronger with the arrival of greater numbers of Indian revolutionaries. The communist 
papers of Tashkent were happy to provide space in their pages for Indian political messaging, and reported frequently on the state of anti-imperial ferment in India. Moreover, Tashkent quickly developed a considerable revolutionary infrastructure. By 1919 a Tashkent chapter of the Moscow-based Union for the Liberation of the Peoples of the East was up and running. ${ }^{9}$ Two Indian revolutionaries, Abdul Majid and Muhammad Shafiq, opened a bilingual Indian newspaper in Urdu and Persian called Zamindar. On 17 October 1920 the same Muhammad Shafiq became a co-founder of the Communist Party of India, along with more famous anticolonial internationalists such as M.N. Roy, Abani Mukherjee, and M.P.T. Acharya. ${ }^{10}$ The Communist Party in Tashkent stood in direct contact with Bengali revolutionary groups such as Anushilan and Jugantar. ${ }^{11}$ In this way, international support for Indian anti-imperialism connected expatriate revolutionaries to their counterparts at home.

If South Asians' connections to New York and San Francisco were facilitated by an increasingly tight network of shipping routes, the roads that led anti-colonial activists to Kabul and on to Tashkent followed well-worn caravan routes across the mountains into Central Asia. ${ }^{12}$ Different locations offered South Asian anti-colonial internationalists access to different types of anti-imperialist politics and, as a result, to different vectors of anti-colonial solidarity. But, thanks to a small but hypermobile number of itinerant South Asian revolutionaries, these sites of anti-colonial internationalism were directly connected. Anti-colonial internationalism was thus both polyphonic and polycentric. The following sections examine different parts of the 'worldwide web' and their ideological signatures, as well as several South Asian anti-colonial activists who threaded these parts together.

\section{The Geneva system and its limits}

After the end of the First World War a new series of opportunities to advocate for Indian independence on the international stage presented itself. President Wilson's Fourteen Points included 'a free, open-minded, and absolutely impartial adjustment of all colonial claims', which inspired anti-colonial activists across Asia and the Middle East. ${ }^{13}$ In addition to the terms of the peace, the Paris Peace Conference included a wide-ranging set of measures to facilitate international contact and conversation in order to prevent future international conflicts from developing. The most important of these was the League of Nations. ${ }^{14}$ In recognition of the Indian war effort, which had included the deployment of over 1 million troops, 700,000 of whom had served in Mesopotamia against the Ottoman Empire, India was granted membership of the League of Nations. ${ }^{15}$ Along with Australia, which was admitted for the same reason, it was the only non-self-governing territory to be included in the League. The League of Nations offered an international platform to advocate for the rights of minorities, women, and colonised populations. ${ }^{16}$ Recent historiography has added the activities of the many official and unofficial organisations and pressure groups in the League's orbit to this narrative. ${ }^{17}$

The importance of the League as an anti-colonial platform should not be overstated, however. The Indian delegates were still part of the larger British delegation, alongside representatives from the metropole, and nor was the Indian National Congress free in the selection of its delegates. As a result, in keeping with social and political expectations at the League of Nations headquarters, most Indian delegates to the League consisted of rulers from the princely states and otherwise loyalist members of the Indian elite. More radical anti-colonial activists, such as Taraknath Das, even went as far as to speak of the intentional misrepresentation of India at the League. ${ }^{18}$

Equally, however, it would be going too far to state that the League of Nations had no value for South Asian anti-colonial internationalism. For several South Asian organisations, it 
functioned as a pedagogical space, offering its members lessons in lobbying, applying political pressure, and gathering support for and solidarity with their cause. The All-India Women's Organization is an excellent example. ${ }^{19}$ Second, if the Indian princes and other community leaders selected to be part of the League's Assembly were largely loyalists, this did not prevent them from standing in solidarity with those to whom they felt kinship. Thus, when the third Aga Khan served as India's chief delegate between 1932 and 1938, he championed the expansion of the League's membership with states outside Europe, in particular Turkey and Iraq $\cdot{ }^{20} \mathrm{He}$ also used his time in Geneva to advocate for Asia at the Red Crescent Society and at the Geneva Conference for the Reduction and Limitation of Armaments. Instead of limiting his political work to South Asia, he saw a wider opportunity to redress the inequity of representation that the 'Geneva system', as it has since become called, accorded to the non-Western world. ${ }^{21}$

Finally, the Geneva system was not limited to the 'Palais Wilson' in which the meetings of the League's Assembly initially took place. In fact, the International Labour Organization (ILO) proved to be the more effective and more lasting of the Wilsonian institutions that emerged from the Versailles Treaty. It is somewhat surprising that the ILO has received far less attention as a site of anti-colonial organising, as it allowed for direct representation. ${ }^{22}$ The tripartite delegations to the ILO consisted of government representatives as well as employers' and workers' delegates. The possibility of nominating the latter had been one of the primary reasons for the establishment of the All-India Trade Union Congress (AITUC) in 1920. The workers' nomination had given AITUC an international dimension from the start, and one that developed further over time.

At the ILO, too, Asian representation was limited, and the Indian delegation worked to maximise its impact. Together with Japanese and Ceylonese delegates, they resolved to bring Asian ILO delegations together six weeks ahead of the annual ILO meeting, in order to be able to advocate for Asia with a united voice. Here too issues of connectivity played a large role: it is no coincidence that the first meeting of the Asiatic Labour Congress took place in Colombo in 1934, a convenient stopover on the way to Geneva for the Japanese delegation. ${ }^{23}$ The Asiatic Labour Congress, however short-lived, saw the mitigation of unequal development resulting from capitalism and imperialism as its primary task. It did have some successes, although the strong Japanese participation became an increasingly contentious issue. When the Congress met in Japan in 1937, just two short months before the outbreak of the Sino-Japanese War, it lost the support of Indian trade union organisations, who sympathised with Chinese workers and not with Japanese labour leaders. The Japanese sponsors of the Asiatic Labour Congress had been critics of Japan's China policy, but the political climate in India had made collaboration with Japanese organisations impossible.

The disintegration of the Asiatic Labour Congress as an organisation of anti-colonial leaders in 1937 was not unique. The All-Asia Women's Congress, an initiative of the All-India Women's Congress, which had first met in Lahore in 1931, suffered a similar fate. Much like its labour counterpart, it argued for the inclusion of an Asian agenda on Asian terms in the international system. In Geneva this meant, among other things, work against the trafficking of women and children and for equal rights for married women, especially the retention of nationality, and, more generally, for the legal status of women. ${ }^{24}$ Ten Indian delegates, among them the Gandhian activist and prominent poet Sarojini Naidu, had attended the International Women's Suffrage Association Conference in Geneva as early as $1920 .{ }^{25}$ In Lahore, they had urged all members of the All-Asian Women's Conference (AAWC) with representation in Geneva to argue for women's rights in the League of Nations' Assembly. ${ }^{26}$ But the 1937 conference of the AAWC was to take place in Japan, and vehement protest from several AAWC members caused a rift that was never repaired. 
In all, the international institutions of Geneva, and organisations elsewhere that subscribed to its principles, did not seek to overthrow existing global power structures. Rather, they aimed at reforming those structures into a more just and equitable world order. Change was to take place within the context of the existing international system, and was geared towards evolution, not revolution. These groups and organisations, often analysed together under the label of 'liberal internationalism' and self-identifying as 'moderate', could and did provide space for anti-colonial activism and solidarity. For those seeking to effect change through mass workingclass solidarity, collective action, or forms of revolution predicated on other outcomes than a world of nation states, however, Geneva was not the preferred site of action. Nevertheless, it is important to note that different sites of anti-colonial solidarity were in constant dialogue with each other, and that the relationship was not always adversarial. Anti-colonial activists also moved between sites as their own politics and interlocutors evolved. In this way, different sites of anti-colonial internationalism co-produced each other. ${ }^{27}$

\section{The Comintern as an anti-colonial body}

The effects of the Bolshevik revolution were felt globally, not least in the colonial world. The first Congress of the Communist International (Comintern) had declared solidarity with anti-colonial struggles, and publicised this fact widely. ${ }^{28}$ In 1920 it organised the Congress of the Oppressed Peoples of the East in Baku, which was attended by 14 Indian revolutionaries. ${ }^{29}$ At this Congress, the plight of workers and peasants in India figured prominently in the proceedings. Moreover, the Baku congress, under the leadership of Comintern chief Grigory Zinoviev, was self-consciously inclusive of Muslim movements, which allayed fears of the Comintern's incompatibility with Asian revolutionary movements. He also stated publicly that the colonial world did need not to pass through a capitalist phase in order to achieve revolution. ${ }^{30}$ The Soviet Union's support for anti-colonial movements appeared to be cemented further in 1921, when Lenin abrogated all secret treaties that had been contracted between Tsarist Russia and the imperialist powers regarding claims to Asian territories. This, too, was hailed widely as an anti-colonial act. In all, it was no surprise that Maulana Barkatullah, one of the small circle of hypermobile revolutionaries whose activities included pan-Islamism in Tokyo, Ghadar work in San Francisco, the wartime expedition to Kabul, and revolutionary work in Tashkent, would write a pamphlet entitled 'Bolshevism and the Islamic nations', in which he proposed modernisation along the Soviet model as the best way forward for Asia. ${ }^{31}$

Indeed, some of the expectations of Soviet support, raised in the aftermath of the revolution, did materialise. If the ILO was an attractive way to achieve direct Indian representation on an international body, the Comintern's Executive Committee included members from the colonial world from the start. Its trade union wing, the Red International of Labour Unions (RILU), was set up as a competing body to the International Federation of Trade Unions, or 'Amsterdam International'. The RILU was far more inclined to support workers' action in India directly. For unionists involved in industrial action, the RILU was a more attractive partner, as it offered material and monetary support towards strikes that other international bodies did not.

For a while, the quest for international recognition meant that the All-India Trade Union Congress was able and willing to send delegations to the ILO and remain on friendly footing with the RILU at the same time. When the RILU established a Pan-Pacific Trade Union Secretariat in 1927, funded from Moscow but aimed specifically at supporting the workers' movement in Asia, AITUC was invited to its founding meeting in Hankou, China. Nevertheless, the Indian trade unionists who were selected to attend the gathering, D.R. Thengdi and S.V. Ghate, were 
barred from travel by the colonial authorities. ${ }^{32}$ The Pan-Pacific Trade Union Secretariat itself continued to reach out to Indian workers over the course of its short lifespan, however, and was especially active among sailors and other transport workers at interstitial spaces such as seamen's clubs. ${ }^{33}$

The denial of passports on the suspicion of 'subversive' politics was a continuing practice, as Daniel Brückenhaus has shown. ${ }^{34}$ It would also come to plague the organisational aftermath of another radical event in 1927: the establishment, in Brussels, of the League Against Imperialism and Colonial Oppression. ${ }^{35}$ The founding congress in Brussels had been primarily attended by anti-colonial activists already present in Europe, such as representatives from Indian student unions in Oxford, Cambridge, and Edinburgh, or exiled revolutionaries such as Virendranath Chattopadhyaya and Barkatullah. A few months after the Congress, however, British authorities used the existing passport system to bar direct contact between the League Against Imperialism and India. Shapurji Saklatvala, a British Indian Labour MP and member of the executive committee of the league, was among those barred. ${ }^{36}$

Despite attempts at suppression from the Dutch, French, and British authorities - even Belgium had allowed the congress to meet in Brussels only on the condition that Belgian Congo was not to be discussed - the League Against Imperialism survived in various forms until 1937. South Asian anti-colonial activists forged connections with their counterparts across the world. Some of the early connections lasted well beyond the lifetime of the league itself, and helped build Afro-Asian cooperation after independence. ${ }^{37}$ Other connections were severed, however, when the Soviet Union entered its 'third period'. Heavily influenced by the Comintern, the league expelled 'bourgeois nationalists' such as Jawaharlal Nehru from its ranks after 1929, as the vision of a broad coalition of the oppressed gave way to that of a more radical revolutionary body. The very name of the League Against Imperialism had been meant to illustrate the frustration felt across the colonised world with the League of Nations in general and the mandate system in particular. With participation from the Americas, Africa and Asia as well as a host of European sympathisers, the league considered itself to be a far more globally representative body, and even self-identified as the 'real' League of Nations. ${ }^{38}$

Both the 'Geneva' and 'Moscow' systems were important sites of anti-colonial solidarity. They also created fractures, however, not least in the Indian independence movement itself. Like the League Against Imperialism, the All-India Trade Union Congress was unable to keep its pro-Geneva and pro-Moscow factions within the same body. This had far-reaching consequences in India itself. The very fact that AITUC split in 1929 over the issue of its international affiliations to the ILO, the Pan-Pacific Trade Union Secretariat, and the League against Imperialism also precluded the possibility of using a full general strike as a political tool. This had serious consequences for the effectiveness of trade unions in the anti-colonial struggle in India. Internationally, the loss of the League Against Imperialism as a platform for a diverse coalition of anti-colonial internationalists in favour of a more exclusive and radical left-wing body likewise stalled the development of a truly global anti-colonial platform.

\section{Regionalist alternatives}

Given the differences in politics between the worlds of 'Geneva' and Moscow', could they be part of the same web of anti-colonial solidarity? Did engagement with one preclude engagement with the other? This question is more complicated than the parting of ways of communists, (democratic) socialists, and sympathisers after the Sixth World Congress of the Communist International in 1928, or the withdrawal of Moscow's funds to the latter two. From a South Asian perspective, the separation of international politics between 'Moscow' and 'Geneva' had 
always been an artificial one. For many anti-colonial activists, the key issue driving their international engagements was the availability of international platforms to argue their cause, and the availability of means (monetary, documentary, and logistical) to do so. Notwithstanding anticolonial activists of deep ideological conviction - such as the aforementioned M.P.T. Acharya to anarchism, or Virendranath Chattopadhyaya to communism - this helps explain how specific regionalist agendas appeared within global platforms. ${ }^{39}$ It also helps explain how South Asian activists were involved in shaping centres of anti-colonial solidarity outside these platforms, not at the centre of Euro-American international life, but at the crossroads of Asianist and Islamist networks. ${ }^{40}$

In the opening decades of the twentieth century Asianism took many forms. ${ }^{41}$ Here, it is understood as the belief that Asian solidarity was a means to achieve independence from the West, whether from formal colonialism or from economic, social, or cultural influences. Some Asianist centres built on existing trading networks and South Asian diasporas, such as Tashkent, noted above. Other centres emerged in the wake of British imperial networks, such as Shanghai. Under Japanese sponsorship of pan-Asianism, Indian anti-imperialists were also cultivated in Kobe and Tokyo. Further pan-Asianist networks were cemented at the pan-Asian conferences organised in Nagasaki and Shanghai in 1926 and 1927, respectively. ${ }^{42}$ Indian activists participated in both conferences, and Indians resident in Japan, such as Rashbehari Bose and Anand Mohan Sahay, helped build an extensive infrastructure to facilitate anti-colonial activism. ${ }^{43}$ They advocated Indian independence through establishing a Japanese branch of the Indian National Congress, promoted Japanese knowledge of India through the Nichi-In Kyōkai (Japanese-Indian Association), and conceived of a post-imperial Asia in journals such as Shin Ajia (New Asia). But they also provided support for South Asian anti-colonial activists directly, by opening houses for Asian students - 'Asia Lodge' in Tokyo and 'India Lodge' in Kobe - where 'students', broadly defined, could stay subsidised in Japan for Rs. 25 , or around US $\$ 7.50$, per month. ${ }^{44}$

Anti-colonial centres outside Europe and the United States allowed for a conceptualisation of a postcolonial world order based not on nineteenth- and twentieth-century Western political ideologies but on other intellectual traditions. In South Asia, cultural and political Asianism dated back to the late nineteenth century, but drew on much older connections and conceptions of Asia. Another alternative was Islamism, where the conception of the umma could also be conceived of as coinciding with the region suffering from Western imperialism. ${ }^{45}$ As part of the worldwide web of anti-colonial solidarity, activists used Islamism not to advocate a singular Islamic state or caliphate (though that, too, occurred) but, rather, to foster a shared set of social, cultural, and political values under threat from, as well as antithetical to, European imperialism.

For South Asia, the Khilafat movement between 1918 and 1924 was a crucial moment in this regard. It was important not least for the many young men, especially from the north-west of British India, who crossed the Pamirs on foot in an effort to reach Anatolia and join the fight for the restoration of the Ottoman caliphate. ${ }^{46}$ But the movements of these muhajirs (migrants) were particularly vital to the formation of anti-imperialist groups and organisations in Asia and the Middle East. When large numbers of muhajirs initially arrived in Kabul, they drew other anti-colonial activists as well as communist agents to that city. Some were recruited into the revolutionary group in Tashkent that would later found the Communist Party of India, and others moved on to Baku to attend the Congress of the Oppressed Peoples of the East. Even if the establishment of the Republic of Turkey in 1924 quashed all hopes of Ottoman restoration, the muhajirs themselves continued to connect anti-imperialist centres ranging from Cairo to Kashgar. An excellent example is Shaukat Usmani, who became a muhajir at just 17 years of age and ended up running a printing press in Kashgar along with fellow muhajir Rafiq Ahmad. ${ }^{47}$ 


\section{Epilogue: Fractures and the resilience of solidarity}

On balance, is it fair to speak of a 'worldwide web' of anti-colonial solidarity? Anti-colonial activism spanned the breadth of the ideological, religious, and social spectrum. Nevertheless, many of the individuals mentioned in this chapter, such as Maulana Barkatullah, Virendranath Chattopadhyaya, and Rashbehari Bose, built connections to anti-imperialists outside South Asia as well as to South Asian activists outside their own political and social circles. Itinerant exiles such as Shaukat Usmani and Mahendra Pratap functioned as the spokes that connected different parts of the web. By the closing years of the interwar period the web of anti-colonial activists and their sympathisers could truly be said to be worldwide, ranging across continents and empires from, in the South Asian case, Vancouver to Munich and from Cape Town to Hong Kong.

As the 1930s progressed, however, this worldwide web came increasingly under attack from different fronts. The Manchurian crisis from 1931 to 1933 and the evolving Japanese activities on the mainland strained movements that revolved around Asian solidarity, and fractured most of them in 1937. The reverberations of the 1929 financial crisis were truly global, restricting both the movement of people and ideas. The rise of Nazism and Fascism impacted many of the organisations mentioned in this chapter, including the raid on the League Against Imperialism's Berlin headquarters, which also destroyed much of its archive. The 'third period' of the Soviet Union did not just solidify ideological boundaries; it also closed off possibilities of forming alliances across different political movements, and cut off funding for much of Moscow's activities in the colonial world.

In South Asia, this combination of hardening ideological lines, financial hardship, and corresponding social unrest culminated in the Meerut conspiracy case of 1929 to 1933, one of the most drawn-out, expensive, and volatile cases in colonial legal history. The case tried 32 activists, revolutionaries, and trade unionists who had, allegedly, entered into a conspiracy to deprive the king emperor of his sovereignty of British India, an offence punishable under section 121-A of the Indian Penal Code. The indictment also listed no fewer than 63 organisations and individuals abroad, however, all suspected of conspiring against the Raj. ${ }^{48}$ It is not an exaggeration to say that the Meerut case put anti-colonial internationalism itself on trial. It was certainly perceived as such at the time, and the shock reverberated through every thread of the web. But, rather than tearing through it, the Meerut case ended up revealing the web's strength. The Meerut prisoners received solidarity from around the world, inspired theatre plays and demonstrations, and showed that anti-colonial solidarity was rapidly growing beyond the reach of imperial control mechanisms. ${ }^{49}$

If the 1930s tested the worldwide web of anti-colonial solidarity, the Second World War disconnected many of its parts from each other. It was not easily destroyed, however. Postwar anti-colonial efforts, such as the Asian Relations Conference of 1947 and the Bandung Conference of 1955, built on connections made in earlier decades, and explicitly acknowledged the efforts that had led them there. ${ }^{50}$ In this way, anti-colonial solidarity laid the groundwork for decolonisation.

\section{Notes}

1 Shompa Lahiri, Indians in Britain: Anglo-Indian Encounters, Race and Identity, 1880-1930 (London: Frank Cass, 1999); Harald Fischer-Tiné, Shyamji Krishnavarma: Sanskrit, Sociology and Anti- Imperialism (Abingdon: Routledge, 2014); Maia Ramnath, Haj to Utopia: How the Ghadar Movement Charted Global Radicalism and Attempted to Overthrow the British Empire (Berkeley, CA: University of California Press, 2011). 
2 Michael Goebel, Anti-Imperial Metropolis: Interwar Paris and the Seeds of Third World Nationalism (Cambridge: CUP, 2015); Mario Prayer, 'Self, other and alter idem: Bengali internationalism and Fascist Italy in the 1920s and 1930', Calcutta Historical Journal, 26 (1), 2006, pp. 1-32; Harald FischerTiné, 'The other side of internationalism: Switzerland as a hub of militant anti- colonialism (c.19101920)', in: idem and Patricia Purtschert (eds.), Colonial Switzerland: Rethinking Colonialism from the Margins (Basingstoke: Palgrave Macmillan, 2015), pp. 221-58.

3 Harald Fischer-Tiné, "Indian nationalism and the world forces": Transnational and diasporic dimensions of the Indian freedom movement on the eve of the First World War', Journal of Global History, 2 (3), 2007, pp. 325-44.

4 Sven Saaler and Christopher Szpilman, Pan-Asianism: A Documentary History, 2 vols. (Lanham, MD: Rowman \& Littlefield, 2011).

5 Kris Manjapra, "The illusions of encounter: Muslim "minds" and Hindu revolutionaries in First World War Germany and after', Journal of Global History, 1 (3), 2006, pp. 363-82, 366.

6 Heike Liebau, 'The German Foreign Office, Indian emigrants and propaganda efforts among the sepoys', in: Franziska Roy, Heike Liebau, and Ravi Ahuja (eds.), 'When the War Began We Heard of Several Kings': South Asian Prisoners in World War I Germany (New Delhi: Social Science Press, 2011), pp. 96-129, 125.

7 Wolfdieter Bihl, 'Zur Indien-Politik des Osmanischen Reiches im Ersten Weltkrieg', Wiener Zeitschrift für die Kunde des Morgenlandes, 82, 1992, pp. 51-66; Pankaj Mishra, From the Ruins of Empire (London: Allen Lane, 2012), esp. ch. 2.

8 For a first-person account of this episode, see the memoirs of expedition member Mahendra Pratap. First serialised in his own publication World Federation, the most accessible republication is Reminiscences of a Revolutionary (New Delhi: Raja Mahendra Pratap Birth Centenary Celebration National Committee, 1986). For the most recent historical analysis, see Jennifer Jenkins, Heike Liebau, and Larissa Schmid, 'Transnationalism and insurrection: Independence committees, anti-colonial networks, and Germany's global war', Journal of Global History, 15 (1), 2020, pp. 61-79.

9 Surendra Gopal, Indian Freedom-Fighters in Tashkent, 1917-1922 (Calcutta: Maulana Abul Kalam Azad Institute, 2002), 10-11.

10 See, most recently, Ali Raza, Revolutionary Pasts: Communist Internationalism in Colonial India (Cambridge: CUP, 2020). On M.N. Roy, see Kris Manjapra, M.N. Roy: Marxism and Colonial Cosmopolitanism (New Delhi: Routledge, 2010); on M.P.T. Acharya and his disagreements with Roy and Mukherjee about the direction of anti-colonial politics, see Ole Birk Laursen, 'An uncompromising rebel: M.P.T. Acharya and Indian anarchism', Kairos, 3 (1), 2018, pp. 66-77.

11 On these organisations, see Joseph Mc Quade's chapter in this volume.

12 On the long history of both mobile and settled Indian connections to Central Asia, see Scott Levi, The Indian Diaspora in Central Asia and Its Trade, 1550-1900 (Leiden: Brill, 2002).

13 Erez Manela, The Wilsonian Moment: Self-Determination and the International Origins of Anticolonial Nationalism (Oxford: OUP, 2007).

14 On the link between the League of Nations and empire, see in particular Susan Pedersen, The Guardians: The League of Nations and the Crisis of Empire (Oxford: OUP, 2015).

15 On India and the League of Nations, see T.A. Keenleyside, 'The Indian nationalist movement and the League of Nations: Prologue to the United Nations', India Quarterly: A Journal of International Affairs, 39, 1983, pp. 281-98; and D.N. Verma, India and the League of Nations (Patna: Bharati Bhawan, 1968).

16 Glenda Sluga, Internationalism in the Age of Nationalism (Pennsylvania: University of Pennsylvania Press, 2013), esp. 45-78. On the (European) minorities issue, see Mark Mazower, 'Minorities and the League of Nations in interwar Europe', Daedalus, 126 (2), 1997, pp. 47-63.

17 Urs Matthias Zachmann (ed.), Asia after Versailles: Asian Perspectives on the Paris Peace Conference and the Interwar Order, 1919-33 (Edinburgh: Edinburgh University Press, 2017); Anne-Isabelle Richard, 'Competition and complementarity: Civil society networks and the question of decentralizing the League of Nations', Journal of Global History, 7 (2), 2012, pp. 233-56; T.R. Davies, 'Internationalism in a divided world: The experience of the International Federation of League of Nations Societies, 1919-1939', Peace \& Change, 37 (2), 2012, pp. 227-52.

18 BL, IOR, L/PJ/12/166, copy of an untitled 1923 pamphlet by Taraknath Das. On Taraknath Das, see Maria Framke, 'Shopping ideologies for independent India? Taraknath Das's engagement with Italian Fascism and German National Socialism', Itinerario, 40 (1), 2016, pp. 55-81; and idem, 'India's freedom and the League of Nations: Public debates 1919-33', in: Zachmann, Asia after Versailles, pp. 124-43. 
19 Carol Miller, 'Geneva - the key to equality: Interwar feminists and the League of Nations', Women's History Review, 3 (2), 1994, pp. 219-45.

20 For a collection of the Aga Khan's speeches at the League of Nations, see K.K. Aziz (ed.), Aga Khan III: Selected Speeches and Writings of Sir Sultan Muhammad Shah, 1928-1955, vol. 2 (London: Kegan Paul International, 1997).

21 Verax, 'Silhouettes étrangères: L'Aga Khan', Revue des Deux Mondes, 13 (2), 1933, pp. 352-59.

22 With the exception of Daniel Roger Maul, 'The International Labour Organization and the struggle against forced labour from 1919 to the present', Labor History, 48 (4), 2007, pp. 477-500.

23 Carolien Stolte, "Bringing Asia to the world": Indian trade unionism and the long road towards the Asiatic Labour Congress, 1919-1937', Journal of Global History, 7 (2), 2012, pp. 257-78.

24 Miller, 'The key to equality'; Jessica Pliley, 'Claims to protection: The rise and fall of feminist abolitionism in the League of Nations Committee on the Traffic in Women and Children, 1919-1936', Journal of Women's History, 22 (4), 2010, pp. 90-113; Barbara Metzger, 'Towards an international human rights regime during the inter-war years: The League of Nations' combat of traffic in women and children', in: Kevin Grant, Philippa Levine, and Frank Trentmann (eds.), Beyond Sovereignty: Britain, Empire and Transnationalism, c.1880-1950 (New York: Palgrave MacMillan, 2007), pp. 54-79.

25 Sumita Mukherjee, 'The All-Asian Women's Conference 1931: Indian women and their leadership of a pan-Asian feminist organisation', Women's History Review, 26 (3), 2017, pp. 363-81, 378.

26 Ibid., 373.

27 For a demonstration of how this dynamic played out, see the special issue Liberal and Illiberal Internationalisms, ed. Philippa Hetherington and Glenda Sluga, in Journal of World History. For the argument of 'co-production' in particular, see Philippa Hetherington and Glenda Sluga, 'Liberal and illiberal internationalisms', Journal of World History, 31 (1), 2020, pp. 1-9, 2.

28 Gangadhar Adhikari, Documents on the History of the Communist Party of India, vol. 1, 1917-1922 (New Delhi: People's Publishing House, 1972), 105.

29 John Riddell (ed.), To See the Dawn: Baku, 1920: First Congress of the Peoples of the East, the Communist International in Lenin's Time (New York: Pathfinder, 1993).

30 Ibid., 114-36.

31 Adhikari, Documents, 121, 126.

32 B.L. Mehta, Trade Union Movement in India (New Delhi: Kanishka Publishing House, 1991), 140; Prem Sagar Gupta, A Short History of the All-India Trade Union Congress (New Delhi: AITUC, 1980), 112.

33 On the PPTUS and Asian maritime workers, see Josephine Fowler, 'From East to West and West to East: Ties of solidarity in the pan-Pacific revolutionary trade union movement, 1923-1934', International Labor and Working-Class History, 66, 2004, pp. 99-117.

34 Daniel Brückenhaus, Policing Transnational Protest: Liberal Imperialism and the Surveillance of Anticolonialists in Europe, 1905-1945 (Oxford: OUP, 2017).

35 On the League Against Imperialism, see Fredrik Petersson, Willi Münzenberg, the League Against Imperialism, and the Comintern, 1925-1933, 2 vols. (Lewiston, NY: Queenston Press, 2013); Michele Louro, Carolien Stolte, Heather Streets-Salter, and Sana Tannoury-Karam. (eds.), The League Against Imperialism: Lives and Afterlives (Leiden: Leiden University Press, 2020).

36 Daniel Brückenhaus, 'British passport restrictions, the League Against Imperialism, and the problem of liberal democracy', in: Louro, Stolte, Streets-Salter, and Tannoury-Karam, The League Against Imperialism, pp. 187-210.

37 For this argument, see Vijay Prashad, The Darker Nations: A People's History of the Third World (New York: New Press 2007), 30. Sukarno also invoked the Brussels Congress at the Bandung Conference in 1955 even though he had not personally attended the former: George McTurnan Kahin, The Asian-African Conference: Bandung, Indonesia, 1955 (Ithaca, NY: Cornell University Press, 1956), 39-40.

38 Michele Louro, Comrades against Imperialism: Nehru, India, and Interwar Nationalism (Cambridge: CUP, 2018), 55.

39 For a detailed account of both men, see Ole Birk Laursen (ed.), We Are Anarchists: Essays on Anarchism, Pacifism, and the Indian Independence Movement, 1923-1953 (Chico: AK Press, 2019); and N.K. Barooah, Chatto: The Life and Times of an Indian Imperialist in Europe (New Delhi: OUP, 2004).

40 For a political analysis of pan-Islamism and pan-Asianism in this period, see Çemil Aydin, The Politics of Anti-Westernism in Asia: Visions of World Order in Pan-Islamic and Pan-Asian Thought (New York: Columbia University, 2007). 
41 For an overview of Indian Pan-Asianism in this period, see Carolien Stolte and Harald Fischer-Tiné, 'Imagining Asia in India: Nationalism and internationalism (c.1905-1940)', Comparative Studies in Society and History, 54 (1), 2012, pp. 65-92.

42 On Asianism and anti-imperialism at these conferences from an East Asian perspective, see Torsten Weber, Embracing 'Asia' in China and Japan: Asianism Discourse and the Contest for Hegemony, 1912-1933 (London: Palgrave Macmillan, 2018).

43 On Rashbehari Bose, see J.G. Oshawa, The Two Great Indians in Japan: Sri Rash Behari Bose and Netaji Subhas Chandra Bose (Calcutta: Kusa Publications, 1954); and Eri Hotta, 'Rash Behari Bose and his Japanese supporters', Interventions: International Journal of Postcolonial Studies, 8 (1), 2006, pp. 116-32. For a brief sketch of Anand Mohan Sahay's activities, see Raman Sinha, 'A forgotten freedom fighter, Anand Mohan Sahay: A colleague of Netaji Subhash Chandra Bose', Proceedings of the Indian History Congress, 63, 2002, pp. 637-43.

44 BL, IOR, L/P\&J/12/163, file on Rash Behari Bose 1923-1926. Note from the British Embassy at Tokyo, 31 May 1933.

45 Çemil Aydin, The Idea of the Muslim World: A Global Intellectual History (Cambridge, MA: Harvard University Press, 2017).

46 On the Khilafat movement, see M. Naeem Qureshi, Pan-Islam in British Indian Politics: A Study of the Khilafat Movement, 1918-1924 (Leiden: Brill, 1999); and Gail Minault, The Khilafat Movement: Religious Symbolism and Political Mobilization in India (New York: Columbia University Press, 1982).

47 M. Ahmad, The Communist Party of India and Its Formation Abroad (Calcutta: National Book Agency, 1962), 30. On Shaukat Usmani's revolutionary travels, see his own Peshawar to Moscow: Leaves from An Indian Muhajireen's Diary (Benares: Swarajy Publishing House, 1927); and, more recently, Raza, Revolutionary Pasts, 52-65.

48 Michele Louro and Carolien Stolte, 'The Meerut conspiracy case in comparative and international perspective', Comparative Studies of South Asia, Africa and the Middle East, 33 (3), 2013, pp. 310-15, 311.

49 Priyamvada Gopal, Insurgent Empire: Anticolonial Resistance and British Dissent (London: Verso, 2019), 245-60; Susan Pennybacker, From Scottsboro to Munich: Race and Political Culture in 1930s Britain (Princeton, NJ: Princeton University Press, 2009), 146-99.

50 Report on the Proceedings and Documentation of the First Asian Relations Conference, New Delhi March-April 1947 (New Delhi: Asian Relations Organization, 1948); George McTurnan Kahin (ed.), The Asian African Conference: Bandung, Indonesia, April 1955 (Ithaca, NY: Cornell University Press, 1956), 40. 